\title{
北海道とサハリンにおける中高年女性の身体活動水準
}

須田 力 ${ }^{*}$ 石川 高行 $^{*}$ 浅尾 秀樹 ${ }^{* *}$ 宅 章介 $^{* * *}$ 布上 恭子 $^{* * * *}$
パスーコフ, P.N.

\section{Physical Activity Levels of Middle-aged and Elderly Women in Hokkaido and Sakhalin Tsutomu Suda ${ }^{*}$, Ishikawa T. ${ }^{*}$, Asao $\mathrm{H}^{* *}$, Miyake S. ${ }^{* * *}$, Nunogami K. ${ }^{* * *}$ Pasyukov P.N. ${ }^{* * * *}$, Shidlovskaya T.N. ${ }^{* * * *}$ and Shidlovsky G.Y. ${ }^{* * * *}$}

\begin{abstract}
The purpose of this study was to evaluate the physical activity level of inhabitants living in snowy and cold regions. Samples are 12 Japanese (Hokkaido) and 13 Russian (Sakhalin) middle-aged and elderly female subjects and their daytime heart rates were measured. Eight of Japanese subjects took a class in calisthenic exercise once a week and five of the Russian subjects in aerobic dance twice a week. The mean of daytime heart rate in the Russian subjects $(82.7 \pm 5.2$ beats/min) was significantly higher $(\mathrm{p}<0.05)$ than that in the Japanese subjects $(76.6 \pm 6.0$ beats $/ \mathrm{min})$. However, the result does not necessarily indicate that the Russian subjects are more active than the Japanese subjects since the difference was thought to have been caused by higher level of heart rate even at rest in the Russian subjects. During no-exercise days, only one of 13 Russian subjects and none of the 12 Japanese subjects satisfied the required intensity and duration of exercise essential for health maintenance that is recommended by American College of Sports Medicine (1990) or Japanese Ministry of Welfare (1989). The aerobic dance seemed to be effective for the maintenance of fitness since the heart rate in four of five subjects during aerobic exercise exceeded the target heart rate level for more than 20 minutes.
\end{abstract}

\section{緒 言}

活発な運動によって高齢者が自立能力を延長させ， ライフスタイルを改善し, 生きがい感を高め, 疾患の 予防に役立つことは自明の事として知られているにも 関らず，多くの人々は人生の大半を非活動的なまま過

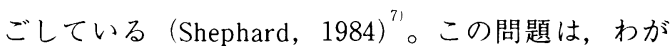
国土の $1 / 2$ を占める積雪地に住む人々，とりわけ女性 にとって重要である。その理由は, 日本の場合，女性 は男性よりも運動する機会が少なく，国民栄養調査 ${ }^{6)}$ によれば一日の歩数の平均值はいずれの年齢階級でも
男性より少ないことと, 積雪・寒冷地では冬季に運動 量が減少することにある。一方, カナダやフィンラン ド ${ }^{10 !}$ の場合は, 日本と違って冬季間も多くの者が活発 にスポーツに参加している。これまでの中高年者のラ イフスタイルと身体活動の研究は，ほとんどがヨー ロッパや北アメリカのものであり, 社会経済的状況, 自然条件の厳しい極東地域の人々についての研究は知 られていない。また, 日本においても小林”, ${ }^{4}$ 岩岡 ${ }^{3)}$, 寄本ら ${ }^{11)}$ の研究は, いずれも降雪のない地域のもので ある。

* 北海道大学教育学部 Faculty of education, Hokkaido University Kita-11, Nishi 7, Kita-ku, Sapporo 060-0811 Japan ** 北海道女子大学 Hokkaido Womens' University, Bunkyodai, 23, Ebetsu 069-0833 Japan

*** 北星学園大学 Hokuseigakuen University, Nishi 2-3-2, Oyachi, Atsubetsu-ku, Sapporo 004 Japan

$* * * *$ 札幌市立高等専門学校 Sapporo School of the Arts, 1-883, Geijutu-no-Mori, Minami-ku 005 Japan

***** ユジノサハリンスク教育大学 Yuzhno-Sakhalinsk State Pedagogical Institute, Lenin St. 290, YuzhnoSakhalinsk, Russia 
北海道と隣接するロシア連邦サハリン州の住民は, 寒冷・積雪の自然環境は北米, 北ヨーロッパや北海道 と共通するが, 共産主義崩壊にともなう社会経済的環 境の悪化により男性の平均寿命が1993年で59歳という 状況からみて, 異なった問題を抱えていると思われ る。以上の問題意識加, 本研究の目的は, ともに寒 冷積雪環境下にある札幌市（日本の北海道）とユジ） サハリンスク市（ロシア連邦サハリン州）に住む中高 年者の女性について身体活動水準を測定し, そのレべ ルが健康で活動的に生きていくために必要な運動所要 量 $^{1225)}$ の強度と時間をどの程度充足しているかを検討 しようとするものである。

\section{方 法}

\section{1. 北海道およびサハリンにおける中高年女性の身体}

活動水準の測定：1995年 9 月から 1996年 5 月にかけ て, 北海道の札幌市及び江別市に住む日本人の中高年 女性12名及びロシア連邦サハリン州ユジノサハリンス ク市に住むロシア人の中高年齢13名の女性の日中の心 拍数を，ハート・レート・モニター（Polar 社製， PE-3000）を使用して記録した。それぞれの被検者の 身体的特性を Table 1 に示す。各被検者に心拍数の記 録の時間带に行動の種類と時間を記録するように依頼 した。被検者は，いずれも医学的な疾患のない健康体 であり, サハリンの被検者は, 教員, 看護婦, 図書館 司書, 主婦などであった。北海道の被検者は, 全員主 婦であった。また，サハリンの被検者のうち 5 名は, 週 2 回のエアロビック体操教室, 北海道の被検者のう ち 8 名は，ストレッチングを主とする体操教室で週 1 回の運動を実施していた。他の被検者は, いずれも定
期的な運動を実施していなかった。運動習慣のある被 検者の測定は，運動日でない日に行った。測定実施に 当たって各被検者に対して研究の目的と方法を説明 し，各被検者から同意を得た。

\section{2. エアロビック体操教室（ロシア）および体操教室}

(日本) の運動強度の測定：エアロビック体操教室に 参加しているロシア人 5 名および体操教室に参加して いる日本人 8 名について習慣的な運動の身体活動水準 を評価するため, 運動中の心拍数を記録した。記録は， 両国とも無雪期に行った。

3. 身体活功水準の評価：各被検者の身体活動水準は, アメリカスポーツ医学協会（以下ACSM と略す, 1991) ${ }^{1 / 21}$ の推奖する「目標心拍数」（すなわち, 最大 心拍数の推定値 (220一年踚) から安静時心拍数を引 いた值 (心拍子備) に0.5を掛け，安静値を加えた值）， あるいは日本の厚生省（1989）の「運動所要量」5) 健康維持のためのレベルを越えた時間から評価した。

4. 統計処理：各群についての身体的特性及び各被検 者の心拍数のデータの平均值, 標準偏差及び度数分布 を算出した。北海道とサハリンの被検者の心拍数の各 平均值の比較は, independent の $\mathrm{t}$ - 検定を用いた。有 意水準の検定は，5\%以下とした。

\section{結果と考察}

1.中高年女性の日中の身体活動水準：Table 1 に示 すように両群の体格は, 身長 $(\mathrm{p}<0.01)$, 体重 $(\mathrm{p}<$ 0.001) および BMI (Body mass index, $\mathrm{p}<0.05$ ) い ずれもサハリンの被検者が有意に大きく，サハリンの 被検者には，インピーダンス法による体脂肪率が $30 \%$ を越える者が多かった。Table 2 およびTable 3 は,

Table 1 Physical characteristics of the subjects.

\begin{tabular}{lccl}
\hline & $\begin{array}{c}\text { Japanese subjects } \\
(\mathrm{N}=12)\end{array}$ & $\begin{array}{c}\text { Russian subjects } \\
(\mathrm{N}=13)\end{array}$ & Difference \\
\hline Age (yrs) & $58.7 \pm 7.1$ & $49.5 \pm 8.2$ & $\mathrm{p}<0.05$ \\
Height $(\mathrm{cm})$ & $153.8 \pm 4.2$ & $159.5 \pm 4.2$ & $\mathrm{p}<0.01$ \\
Weight $(\mathrm{kg})$ & $53.3 \pm 6.5$ & $67.9 \pm 11.4$ & $\mathrm{p}<0.01$ \\
Body mass index & $22.6 \pm 2.9$ & $26.7 \pm 4.7$ & $\mathrm{p}<0.01$ \\
\%Fat & $28.1 \pm 5.8$ & $38.0 \pm 9.1$ & $\mathrm{p}<0.01$ \\
\hline
\end{tabular}


北海道およびサハリンの被検者の身体活動水準の個別 および全体の平均値の結果を示す。なおエアロビック 教室および体操教室時の記録は，このデータに含まれ ていない。Fig. 1 に北海道の被検者の記録例を示す。 彼女はこの日, 部屋の清掃, 息子の引越の準備の手伝 いで荷物の片づけなどの身体活動に従事していたが, 目標心拍数108拍/分を越える機会はほとんど皆無で あった。Fig. 2 にサハリンの被検者の記録例を示す。 この被検者は, 出勤時と昼休みの街中散歩時に散発的
に目標心拍数124拍/分を越える機会があったものの， 持続時間の条件では有酸素性能力の維持に必要な量を 満たしていない。しかし, 夕方 6 時からのエアロビッ クス教室では, 目標心拍数を越える強度が40分間持続 した。個別の心拍数の平均値から群全体の平均值を算 出した結果は, サハリンの被検者群が82.7

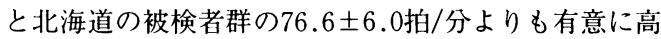
かった。しかし, 安静時の心拍数の平均值は, サハリ ンの被検者群が $68.1 \pm 5.4$ 拍/分と北海道の被検者群の

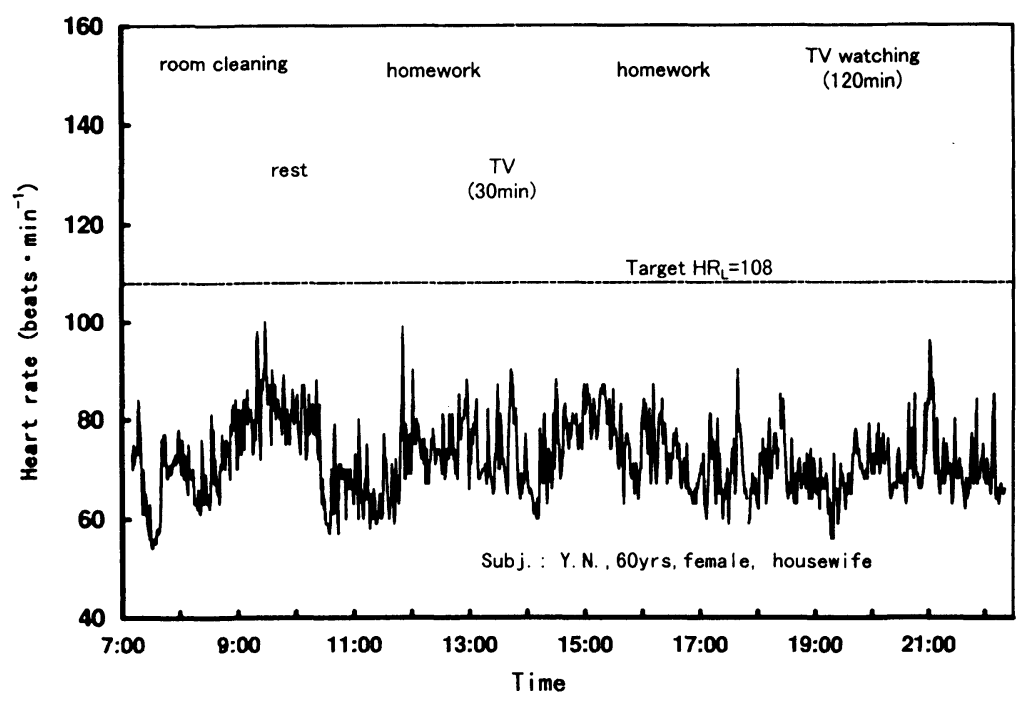

Fig. 1 Daytime heart rate trendgraph in a Japanese female subject.

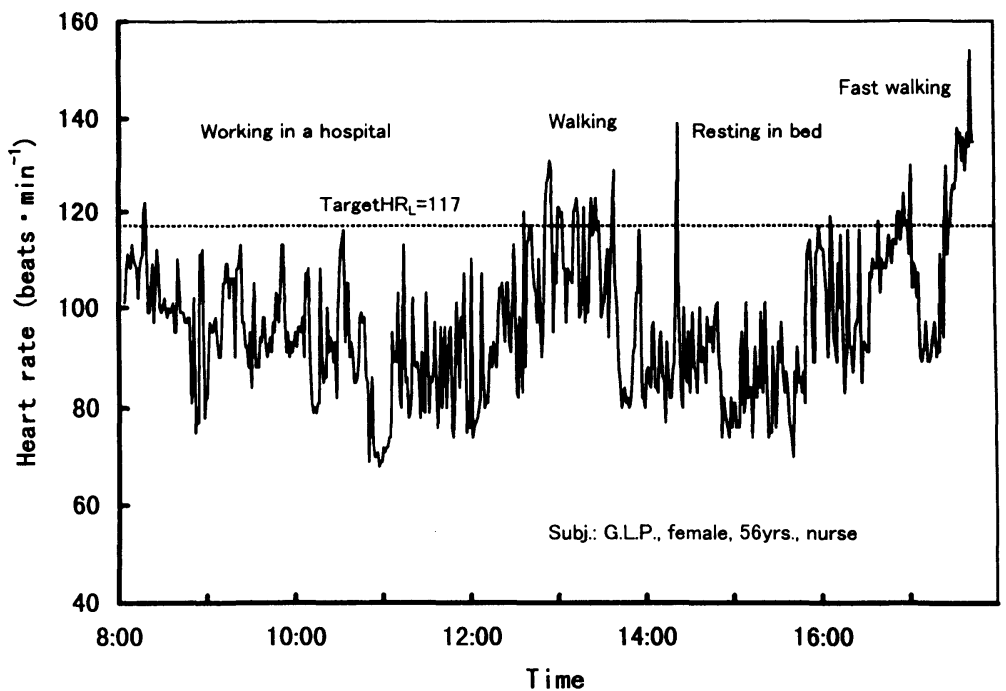

Fig. 2 Daytime heart rate trendgraph in a Russian female subject. 
$62.5 \pm 5.0$ 拍/分よりも5.6拍高かった $(\mathrm{p}<0.05)$ ため, サハリンの被検者の方が身体的に活動的であったとい う判断はできない。岩岡ら ${ }^{3 \prime}$ が雪のない地域の高齢者 に実施した覚醒時の心拍数は, 男性 6 名の平均值74拍/ 分, 女性13名の平均値79拍/分と本研究とほぼ同レ心 ルであった。また, 積雪地における先行研究と比較す ると, 今回の結果は須田と中川 ${ }^{91}$ が札幌市に住む高齢 者達に対して積雪期と無雪期に実施した日中の心拍数
の記録より 3 拍/分高い程度で，特別な運動を実施し ない日常生活の身体活動水準では，健康で活動的に生 きていくために必要な運動強度と時間が不足している ことが改めて指摘された。ACSM の推奨する運動所要 量は,（1）運動強度は, 最大心拍数の60－90\%か最 大酸素摂取量の50〜85\%，（2）時間は，20６0分間 の持続的な有酸素性運動，（3）頻度は, 週当たり 3 5 日，とされている。本研究においては, サハリンの

Table 2 Results of the daytime heart rate recordings in 12 Japanese female subjects.

\begin{tabular}{|c|c|c|c|c|c|c|c|c|}
\hline \multirow[t]{2}{*}{ Subj. } & \multirow{2}{*}{$\begin{array}{l}\text { Age } \\
\text { (yrs) }\end{array}$} & \multicolumn{4}{|c|}{ Heart rate (beats/min) } & \multirow{2}{*}{$\begin{array}{l}\text { Target HR by } \\
\text { ACSM (bpm) }\end{array}$} & \multirow{2}{*}{$\begin{array}{l}\text { Exceeded time over } \\
\text { Target HR (min) }\end{array}$} & \multirow{2}{*}{$\begin{array}{l}\text { Exceeded time over } \\
\text { Japanese level (min) }\end{array}$} \\
\hline & & Min & $\operatorname{Max}$ & Mean & SD & & & \\
\hline N.H. & 45 & 48 & 113 & 74.7 & 11.5 & 115 & 2 & 0 \\
\hline M.M. & 47 & 56 & 144 & 84.3 & 17.1 & 117 & 51 & 22 \\
\hline S.S. & 52 & 54 & 121 & 75.0 & 11.3 & 117 & 2 & 0 \\
\hline K.K & 54 & 62 & 118 & 77.3 & 9.4 & 116 & 3 & 0 \\
\hline N.S. & 54 & 66 & 147 & 91.1 & 15.3 & 118 & 34 & 17 \\
\hline Y.N. & 60 & 48 & 100 & 71.9 & 7.9 & 108 & 0 & 0 \\
\hline K.I & 60 & 55 & 128 & 74.8 & 8.0 & 113 & 3 & 2 \\
\hline N.U. & 61 & 57 & 117 & 77.5 & 8.6 & 115 & 1 & 0 \\
\hline S.T. & 65 & 52 & 96 & 67.2 & 8.4 & 105 & 0 & 0 \\
\hline S.S. & 65 & 58 & 116 & 78.6 & 9.7 & 108 & 3 & 0 \\
\hline K.S. & 67 & 55 & 109 & 70.5 & 8.9 & 109 & 1 & 0 \\
\hline E.S & 70 & 57 & 135 & 76.4 & 10.6 & 108 & 5 & 0 \\
\hline Mean & 58.4 & 55.7 & 120.3 & 76.6 & 10.6 & 112.4 & 8.8 & 3.4 \\
\hline SD & 7.6 & 4.9 & 15.2 & 6.0 & 2.7 & 4.5 & 16.2 & 13 \\
\hline
\end{tabular}

Note:

"Target HR" means the lower limit of the heart rate calculated by $(220-$ Age $) \times 0.5+$ Resting heart rate (ACSM).

"Japanese level" denotes the level recommended by the Ministry of Welfare in Japan (1989).

Table 3 Results of the daytime heart rate recording in 13 Russian female subjects.

\begin{tabular}{c|c|cccc|c|c|c}
\hline Subj. & Age & \multicolumn{2}{|c|}{ Heart rate } & (beats/min) & Target HR by & $\begin{array}{l}\text { Exceeded time } \\
\text { over }\end{array}$ & Exceeded time over \\
& (yrs) & Min & Max & Mean & Min & ACSM (bpm) & Target HR (min) & Japanese level (min) \\
\hline L.V.G & 48 & 64 & 120 & 80.9 & 11.3 & 121 & 0 & 1 \\
G.L.P. & 56 & 63 & 116 & 79.3 & 12.4 & 117 & 0 & 6 \\
K.G.I & 41 & 68 & 154 & 96.8 & 14.3 & 127 & 19 & 37 \\
A.A.M. & 65 & 72 & 110 & 87.6 & 7.2 & 118 & 0 & 2 \\
K.L.A & 55 & 53 & 134 & 81.1 & 14.7 & 113 & 11 & 11 \\
P.G.P & 56 & 53 & 115 & 76.2 & 11.8 & 112 & 3 & 0 \\
K.N.P & 63 & 65 & 109 & 77.9 & 6.9 & 114 & 0 & 0 \\
G.L.A. & 47 & 61 & 138 & 82.4 & 15.3 & 119 & 13 & 10 \\
M.T.1 & 42 & 59 & 112 & 80.4 & 10.3 & 122 & 0 & 0 \\
O.T.P & 42 & 65 & 142 & 84.9 & 12.6 & 124 & 9 & 11 \\
M.V.V. & 45 & 58 & 118 & 83.9 & 17.7 & 120 & 0 & 13 \\
K.L.P. & 41 & 56 & 145 & 80.8 & 17.0 & 122 & 11 & 1 \\
C.J.A & 42 & 63 & 125 & 82.9 & 12.3 & 124 & 0 & 7.1 \\
\hline Mcan & 49.5 & 55.7 & 126.0 & 82.7 & 12.6 & 119.5 & 5.1 & 10.3 \\
S.D. & 8.6 & 5.6 & 14.9 & 5.2 & 3.3 & 4.6 & 6.2 & \\
\hline & & & & & & & & 0 \\
\hline
\end{tabular}


被検者中 8 名, 北海道の被検者中 4 名が $60 \% \mathrm{HR}_{\max }$ を 越えた時間が一日のうち60分間以上出現した。しか し，安静時心拍数が高い場合このような高進は谷易に 出現するであろうし，サハリンの被検者群の安静時心 拍数の平均値が北海道の被検者群よりも有意に高かっ たことから，北海道の被検者群よりも活動的であった 結果かどうかは疑問である。日本の厚生省の「健康づ くりのための運動所要量」（1989）によれば，（1）安 静時の心拍数70拍/分の 40 歳台, 50 歳台, 60 歳台の適 当な運動強度は, $50 \% \mathrm{VO}_{2 \max }$ に相当する心拍数とし てそれぞれ120，115および110拍/分，（2）時間は, 一回当たりが少なくとも10分間以上で 20 分間以上,

（3）頻度は，毎日が望ましい，としている。Table 2 および Table 3 に示すように, ACSM の目標心拍数の 下限を連続して越えた時間が連続して10分間以上見ら れた者は，サハリンの被検者の13名のうち 1 名 (K.G.I) のみで, 北海道の被検者では12名のうち皆無であっ た。また, 日本の厚生省による「運動所要量」の目安 における $50 \% \mathrm{VO}_{2 \max }$ に相当する心拍数を越えた時間
が20分間以上あったものはサハリンの被検者, 北海道 の被検者でそれぞれ 1 名であったが, 10分以上持続し た者は上記のサハリンの被検者のみであった。これら の心拍数の増加は, 前者は自宅から勤務先までの通勤 時の歩行, 後者は自宅から店舗までの買い物のための 歩行時のものであった。

\section{2. エアロビック教室, 体操教室における身体活勒水}

準：サハリンの被検者 5 名のエアロビック教室受講時 の心拍数の平均值は, 105 143, 平均 $121 \pm 16$ 拍/分で あった (Table 4)。各自の目標心拍数を越える強度が 20分間以上持続した者は 5 名中 4 名いたことから,こ の教室が健康維持のために効果的な役割を果たしてい ると思われた。一方, Table 5 に示す北海道の被検者 8 名の体操教室中の心拍数の平均值は, 86 115, 平 均 $99 \pm 10$ 拍/分とエアロビック体操教室よりも低めで あった。この体操教室は, ストレッチングを主とする 杂軟性の向上など運動機能の改善を図るためのもので あることと, 受講考の中に骨粗鬆症の者や関節障害の ある者もいたため high impact exercise が含まれない

Table 4 Activity levels in 5 Russian subjects during aerobic dance exercise.

\begin{tabular}{c|c|ccc|c|c}
\hline Subj. & Age & \multicolumn{3}{|c|}{ Heart rate (beats/min) } & Target HR & Exceeded \\
& (yrs) & Range & Mean & SD & by ACSM & Time(min) \\
\hline M.T.I. & 42 & $103-164$ & 142.6 & 14.1 & 122 & 57 \\
O.T.P. & 42 & $91-166$ & 135.9 & 21.5 & 124 & 42 \\
M.V.V. & 45 & $81-126$ & 107.2 & 12.3 & 120 & 6 \\
K.L.P. & 41 & $77-136$ & 113.5 & 14.3 & 122 & 23 \\
C.J.A. & 42 & $84-125$ & 104.7 & 8.0 & 124 & 2 \\
\hline Mean & 42.4 & $87-143$ & 120.8 & 14.0 & 122.4 & 26 \\
SE & 1.4 & $4.6-9.0$ & 15.5 & 4.9 & 1.3 & 10.5 \\
\hline
\end{tabular}

Table 5 Activity levels in 8 Japanese subjects during calisthenics exercise.

\begin{tabular}{c|c|ccc|c|c}
\hline Subj. & Age & \multicolumn{2}{|c|}{ Heart rate (beats/min) } & Target HR & Exceeded \\
& (yrs) & Range & Mcan & SD & by ACSM & Time(min) \\
\hline N.H. & 45 & $60-129$ & 88.0 & 18.5 & 115 & 3 \\
M.M. & 47 & $73-157$ & 105.6 & 18.2 & 117 & 11 \\
S.S. & 52 & $63-128$ & 92.6 & 14.3 & 117 & 7 \\
K.K. & 54 & $79-159$ & 115.0 & 22.7 & 116 & 22 \\
N.S. & 54 & $71-153$ & 106.9 & 21.9 & 118 & 19 \\
Y.N. & 60 & $64-117$ & 86.1 & 13.7 & 108 & 1 \\
N.U. & 60 & $72-144$ & 108.2 & 18.1 & 115 & 20 \\
K.S. & 67 & $68-134$ & 91.1 & 13.6 & 109 & 8 \\
\hline Mean & 54.9 & $69-140$ & 99.2 & 17.6 & 114.3 & 11.4 \\
SE & 6.8 & $2.2-5.5$ & 10.2 & 1.3 & 1.3 & 2.8 \\
\hline
\end{tabular}


プログラムであったため, 運動機能の改善や運動不足 を補う役割は果たしているものの, 呼吸循環機能の維 持, 改善の効果としては不十分であったと判断され た。

寒冷が北海道よりもさらに厳しいサハリン州では, 計画経済から市場経済への移行に伴うさまざまな混乱 が貧富の差の増大，教育や医療への国家からの予算配 当の激減, 治安の悪化などの問題を引き起こし, それ が住民の健康, スポーツ振興へさまざまな影を落とし ている。北海道においても, 過疎化, 老人医療費日本 一などの問題の中で, 地域の再生と自立能力を高める ために運動による健康増進，地域の活性化はますます 重要な役割をになっている。このような地域において は寒冷積雪環境に負けない活動的なライフスタイルを 定着させるための取り組みが共通の課題である。

\section{結 論}

ロシア連邦ユジノサハリンスク市に住む中高年ロシ ア人女性 13 名および北海道に住む中高年女性 12 名につ いて心拍数記録により身体活動水準を测定した結果, 両地域とも大部分の被検者は健康維持に必要な運動量 が不足していること，アエロビック体操のような定期 的な運動が, 体う」の保持に重要な役割を果たしている ことが示唆された。

本研究の一部は, 平成 8 年度文部省科学研究国際学術 研究 (国際協少研究) の助成によるものである。

\section{参考文献}

1) American College of Sports Medicine (1990) The Recommended Quantity and Quality of Exercise for Developing and Maintaining Cardiorespiratory and Muscular Fitness in Healthy Adults. Medicine and
Science in Sports and exercise, Vol.22:265-274.

2 ) American College of Sports Medicine (1991) Guidelines for Exercise Testing and Prescription: Forth Edition, Lea \& Febiger, Philadelphia.

3 ) 岩岡研典（1985）高齢者の日常身体活動水準. （福武 直, 原澤道美編「高齢者社会の保健と医療」） 東京大学出版会, pp.312-319.

4 ）小林寛道, 近藤孝晴（1985）高齡者の運動と体力. 朝倉書店, pp.89-94.

5 ) 厚生省, 健康づくりのための運動所要量策定検討 委員会（黒田善雄委員長）（1989）健康づくりのた めの運動所要量策定検討委員会報告書.

6 ) 厚生省保健医療局健康増進栄養課監修（1993）国 民栄養の現状．第一出版，pp. 126.

7 ) Shephard R.J. (1984) Management of Exercise in the Elderly. Can. J. Appl. Spt. Sci. Vol.9 : 109-120.

8 ）進藤宗洋（1990）厚生省の「健康づくりのための 運動所要量について」一身から錆を出さない, 出さ せない』暮らし方の提案一. 保健の科学, 第 32 巻 3 号139-156.

9 ) 須田 力, 中川功哉（1993）積雪地における高齢 者の生活で発揮される体力に関する研究. 平成 4 ・ 5 年度科学研究費補助金一般研究(C)) 研究成果報告 書, pp.12-28.

10) Vuolle P., Telama R., and Laaksol, L. (1986) Physical activity in the lifestyle of Finnish adults. Scand. J. sports Sci. Vol.883 : 562-565.

11）寄本 明,佐藤尚武, 武部吉秀, 岡本 進, 森本 武利（1992）高齢者の生活活動強度と一日のエネル ギー消費量. 臨床スポーツ医学, Vol.9, No.9： 1020-1026.

(1998年2月24日受付，5月19日受理) 